\title{
微粉脫水用連続遠心脫水機の操業成績について
}

\author{
正会員林 \\ 喜 芳* \\ 正会員斎藤善 男**
}

\section{Dewatering Flotation Froth of Fine Coal with Continuous Centrifuge}

Kiyoshi HAYASHI and Yoshio SAITO

Several tests have been made with continuous centrifuges for the purpose of dewatering the flotation froth of fine coal at Sakito (Nagasaki) and Bibai (Hokkaido) collieries, Mitsubishi Coal Mining Co., Ltd.

The results of the tests and performances in actual operations are summarized as follows:

1) The continuous centrifuges tested were proved to be applicable for dewatering fine coal froth.

2) The effectiveness of dewatering and capacity of the machine are greatly affected by the percentage of minus 300 -mesh particles in the feed.

3) The ash content of the dewatered coal is about 4 percent lower than that of the feed, owing to the desliming action of the machine.

4) Considering the lives of wearing parts, the speed of rotation and the difference between the speed of outer bowl and inner screw should be preferably low.

5) The dewatering cost is about 170 to 200 yen per ton of dewatered coal.

\section{1. 緒}

言

微粉炭の機械的脱水については，早くから諸外国にお いて幾多の研究がなされてきたが，わが国でも特に戦後 になつて浮遊選炭の普及発達と共に，これに関する技術 の導大を見るに至つた。一般に従来最も多く採用されて いるのは, シックナとフィルタによる脱水法であるが， これには相当の建設費と床面積を要するので，当社では 遠心脱水機の採用を試みることにした。

昭和 25 年12月わが国Ｉ社製バード型試験機により，当 社微粉宸中最も微粒子の多く，脱水困難な崎戸の微粉炭 を対象として基礎的試験を行つたところ，一応の成果を 挙げ得たので，さらにI社に試験機を製作させ，昭和 27 年 3 月崎戸硝業所に設置して現場試験を行つた。昭和 28 年 4 月崎戸の浮選設備の完成により，連続操業に大ると 共に，さらに，昭和29年 9 月改良型 1 基を増設し, 当続 き現在に至るまで操業中である。また美唄砥業所におら ても，昭和 29 年 4 月 $\mathrm{S}$ 社製遠心脱水機知置し，浮選設 備完成々同時に連続運転に大つた。両㞸砇共に現在一応 の成果を挙げうつあるので，ここにその操業成績につい て報告する。

\footnotetext{
* 三菱鉱業株式会社生產部副長策選炭課長

**同上選炭課長代理

1) 林 喜芳, 大本武次：選炭 No. 3 (1951) 1 5
}

\section{2. 設 備 の 概 要}

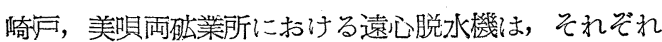
第1図および第 2 図に示すような浮選系統の中に入れて 浮選精崖の脱水を行つている。

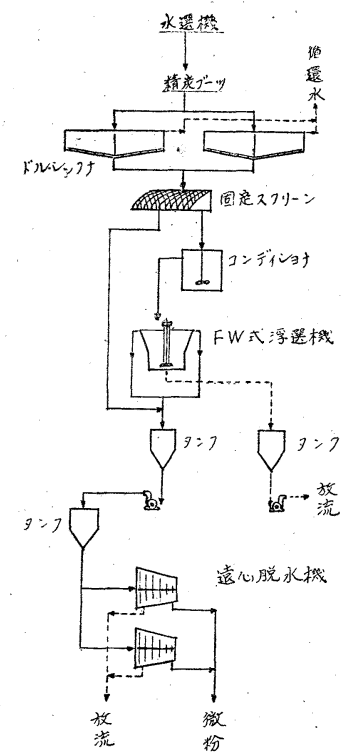

第1図槣戶浮選系統

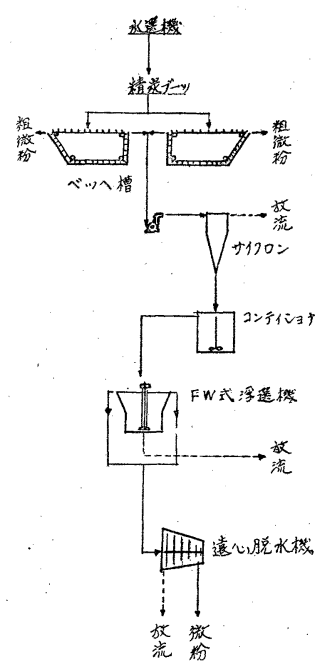

第 2 図 美唄浮選系統 


\section{3. 連続遠心脫水機の構造之仕様}

（第3図および第 1 表参照）

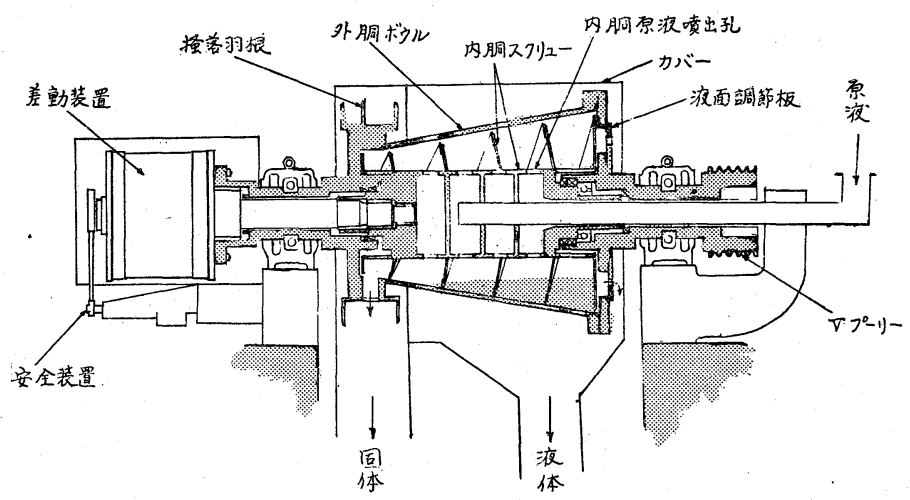

第 3 図遠心脫水機の構造図（崎F）
可能になる状況であつた。ボウル径 $600 \mathrm{~mm}, 2,000 \mathrm{rpm}$, 遠心効果 $900(\mathrm{~g}$ の 900 倍) 程度では， -300 mesh が 50\%以上も原料中に含まれるもの观 理することは無理の様に思われた。

(1)については内胴スクリュー先端部

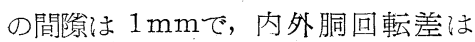
$45 \mathrm{rpm}$ であつたが，この回転差はやや 多きに過ぎ，運転時間計 $150 \mathrm{~h} に$ に間 吵が 6〜7 mmに磨耗し, 外胴内壁に微 粉が固着する様になり，漸くバランス 虎保つている程度であつた。

@については内外胴のアンバランス による周期的な騒音と振動 (5/100mm 以上）がかなりあり，検討の結果整備
第 1 表 遠心脫 水機仕梂

\begin{tabular}{|c|}
\hline 諎 置 場 所 \\
\hline 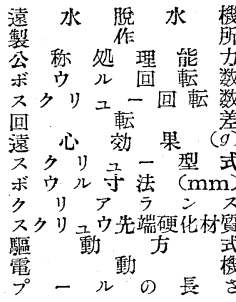 \\
\hline
\end{tabular}

\section{4. 試験運転成績}

崎戸砥業所においては昭和 28 年 3 月以降浮選設備完成 と共に第一次，第二次連続運転試験を実施した。そその概 要および試験成績は次の通りである。

\section{1 第一次試 験}

第一次試験は第 2 表に示す如き仕椂の脱水機で行つた が，次の点に欠陥があつたため連続運転如不可能となつ た。

(1) 連続的に吐出固形物が出ないこと。

(口)内胴スクリュー先端部の磨耗が甚だしく，耐用 時間が 150 h程度であつたこと。

(1) 回転部分のバランスが不調であつたこと。 (け:こついては原料中のー300 mesh の微粉分が50\%〜 $60 \% に$ も達したため，吐出固形物が粘着力強く，䄮ル カバー内壁に固着する様になり，2〜3hで連続運転が不

第 2 表 遠心脫 水機仕様

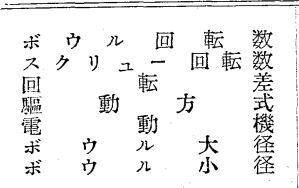

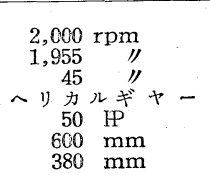

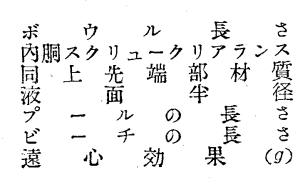

美唄

\begin{tabular}{|c|c|}
\hline $\begin{array}{l}S \\
4 t / 1 \\
1200 \\
1185\end{array}$ & 社 \\
\hline 约 $\begin{array}{r}15 \\
450\end{array}$ & 11 \\
\hline 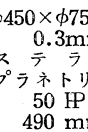 & $\begin{array}{l}\times l 960 \\
1 \\
1 \\
\text { ギャ }\end{array}$ \\
\hline
\end{tabular}

の必要が痛感されたので,

一部仕様の改変と共にバラ ンスの調整をとる様にし た。

第一次尌験の結果, 給液 中に- $300 \mathrm{mesh}$ の微粉を $60 \%$ 前後含孔ものは，処理 能力 (脱水精炭) $0.5 \mathrm{t} / \mathrm{h}$, 収 率70\%以下となり，精炭の

連続吐出が困難になることがわかつたので，外胴吐出部 に搔出羽根を取付けて，その促進を企図したが無理であ つた。ー300mesh 30〜40\%のものは, 观理量(脱水精炭) 約 $1.7 \mathrm{t} / \mathrm{h}$, 収率 85〜92\%となり，精炭吐出は連続的に 行われた。この時の給液濃度は $23 \%$ 前後, 精㟶湿分は 22 〜 19\%, 排水濃度 3\%, 品位は給炭灰分18～22\%，精孷 灰分14〜16\%，排水中の固体の灰分45～60\%であつた。

\section{2 第二次試 験}

第一次試験の成績に鑑み検討支加えた結果，脱水機の 仕様の内, 回転差を $20 \mathrm{rpm}$, 間隙虔 $0.5 \mathrm{~mm}$, 内胴 クリュー肉盛材質を神卧制 HF \#12 に変更し, I 社に おいて本機の整備を行つた。同時に浮選機及びドル・シ ックナの捛業にも再検尌を加え，浮選前に $30 \mathrm{mesh}$ 固 定ス方ーンで比較的品位良好な粗粒分の直接回収を行 い，これ孝浮選フロスに加えると共に，浮選尾水への粗 粒分の逃炭防止衼子等, 多少操業條件を工夫して昭和 28 年 8 月下旬試験運転屏開 始した。

4.2 .1 液面半径 $270 \mathrm{~mm}$, プールの長さ $170 \mathrm{~mm}$ 場合 整倩後当初は前記と同じ 
條件で運転を実施したが，ビーチの長さが長過ぎたため に処理量は所期の目標に到達せず，消費電力も据付馬力 $35 \mathrm{~kW}$ の $75 \%$ 消費して，ピーク時を考慮すれば著 しく安定性を欠く状態であつた。またギャボックス，ボ

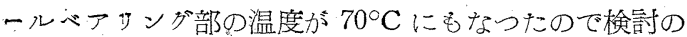
結果，脱水能力を多少犠牲に乙て，如理量の増加に主眼 を抢くことにし，液面半径を $230 \mathrm{~mm}$ に変更し，引続き 運転を実施した。

4.2 .2 液面半径 $230 \mathrm{~mm}$, プールの長さ $395 \mathrm{~mm}$ の 場合

液面半径 $230 \mathrm{~mm}$ における内胴スクリューの磨耗状態 並びに故障程度を知る為に長期連続運転を実施したが， 人員関係，機械的不㓮れ等のため所期の成果を挙げ得な からた。その成績は次の通りであつた。

(1) 供給 原 料

給液濃度は25〜30\%が適当である。遠心効果 900 程 度 (外胴回転数 2,000 rpm) では, -300 mesh が 30 〜 40\%程度ならば，脱水炭は連続的に排出されて取扱 い易くなる。

(10)脱水岸

原料の粒度に左右されるが水分 $22 \%$ 程度で取扱容易 であつた。搔出量は $2 \sim 3 \mathrm{t} / \mathrm{h}$ ，回収率は 85 90\%で， 灰分は 15〜17\%，すなわち，3４\%の灰分低下を見た。 (1) 尾 水

濃度は $5 \%$ 前後で, 固形物の灰分は $44 \sim 51 \%$, 粒度 はー300 mesh が 100\%である。

$\ominus$ 機械管理，その他

・電力消費量……搔出精炭 $2 \sim 3 \mathrm{t} / \mathrm{h} に \tau$. 14 $21 \mathrm{~kW}$ 程度。大体固形物処理量ならびにビーチの長さに比例 する。

・振動……振動が 5/100 mm以上は調整を要す。

・スクリューの碳耗……材質 HF $\# 12$, 回転差 20 $\mathrm{rpm}$ で約 $1,500 \mathrm{~h} に 3 \mathrm{~mm}$ 程度磨耗するので, 定期的 に肉盛り及びバラシシング調整を必要とする。

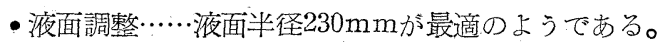

\section{5. 操 業 成 績}

浮選精炭の眖水に一态の成果を収めることが出来たの で, 崎戸吰業所においては昭和29年 8 月, 处理量の增大 を四るベく 2 号機（改良型）を増設し，試運転しながら 穖械的な耐用度, 故障の程度, 所要経費等を見究めつつ 12 月より，また美唄唏業所は 7 月より前記機械的條件 （第1表）のもとに本格的操業に大った。年の成績は次 の通りである。

操業に抢いては，ボウル回転数を崎户では $2,000 \mathrm{rpm}$ を 1,600 rpm に，美唄では $1,600 \mathrm{rpm}$ を 1,200 rpm に それぞれ変更した。その理由は，崎戸では回転数を落と

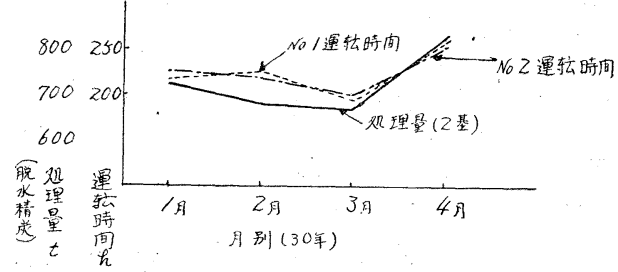

第4図 運転時間と処理量（陭戶)

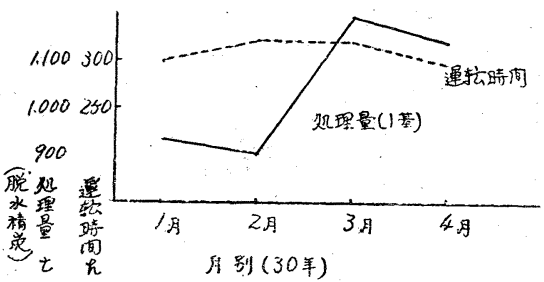

管 5 図 運転時間と処理量（美唄）

しても脱水程度・処理量ともに変化が認められなかった ので，消費電力を節約乙耐用命数の向上をはかるため， まだ美唄では正規の回転速度では振動が増し，連続運転 に堪えられない見通しであったためである。

\section{1 運転時間と処理量}

正常運転に大つてからの運転封間と好理量の関係を四 示すると第4図抢よび第5 図のごとくなる。

崎戸では水選譏の運転時間とドルシッククにおおける微 粉の沈降の間に時間的ズレがあり，一方眖水機は連絸運 転を行つているため，处理量は平均寸る之1基当り 1.6 $\mathrm{t} / \mathrm{h}$ (脱水精炭)になる。乙か乙正常な運転状態では 1.8 $\sim 2.3 \mathrm{t} / \mathrm{h}$ (脱水精炭), 給液中に粗粒分の多心場合は最 高約 $4 \mathrm{t} / \mathrm{h}$ (脱水精炭) 以上も処理することがある。美唄 の場合の平均処理量は約 $3.4 \mathrm{t} / \mathrm{h}$ (脱水精炭) である。

第 3 表 月別故障時間及び個所

\begin{tabular}{|c|c|c|c|c|c|c|}
\hline \multirow{3}{*}{$\begin{array}{l}\text { 月 } \\
\text { 別 }\end{array}$} & \multicolumn{2}{|l|}{ 崎 } & \multirow{2}{*}{\multicolumn{2}{|c|}{$\begin{array}{c}\text { 巨 } \\
2 \text { 号機 (改良型) }\end{array}$}} & \multirow{2}{*}{\multicolumn{2}{|c|}{ 美暊 }} \\
\hline & 1 号 & & & & & \\
\hline & 故障個所 & $\begin{array}{l}\text { 休薽 } \\
\text { 間 }\end{array}$ & 故㜔個所 & $\begin{array}{l}\text { 休䡆 } \\
\text { 時間 }\end{array}$ & 故㜔個所 & $\begin{array}{l}\text { 休転 } \\
\text { 間 }\end{array}$ \\
\hline $\begin{array}{r}30 \text { 年 } \\
1\end{array}$ & 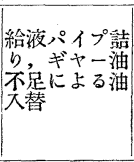 & 3.30 & $\begin{array}{l}\text { 給液パイプ詰 } \\
\text { ○駱動ギヤ } \\
\text { 一洩油調節 }\end{array}$ & 12.50 & 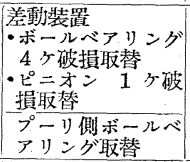 & 7.40 \\
\hline 2 & し & - & 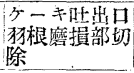 & 3.10 & 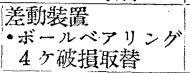 & 隹粠 \\
\hline 3 & な & - & L & - & 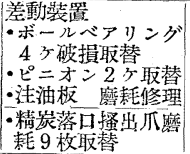 & 32.50 \\
\hline 4 & 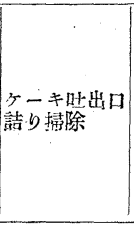 & 1.10 & 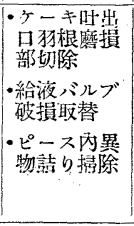 & 2.45 & 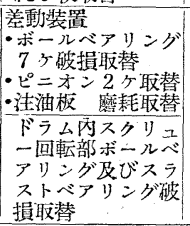 & 59.40 \\
\hline
\end{tabular}




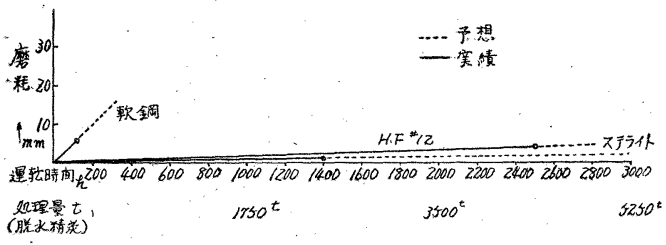

第6図スクリューの磨耗と運転時間(崎戶)

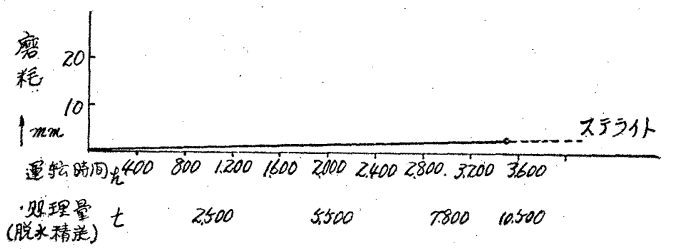

第 7 図、スクリューの磨耗と運転時間（美唄）

\section{2 故障の発生状況之その対策}

月別故障時間と個所第 3 表に示す。

遠心脱水機の故障の原因は大部分差動装置関係之スク リューの磨耗である。差動装置関係では畨車の精度およ び材質によるものと，振動または給油方式の欠陥による ベアリングの損耗が多い。崎戸の改良型ではそれ等が改 善されたが，美唄は初期の製品であるため，第 3 表に示 す如く，故障が多い。一方スクリューの硒耗がひどいと 間隙が大となり，回転体のバランスが崩れ，振動を起す ことになるので，スクリュー予借品を持つか，あるいは スクリュー先端の硬化材熔接技術に習熟することが肝要 である。またべアリングはその温度, 油の状態等に常に 注意すへきである。

\section{3 スクリューの磨耗}

運転時間とスクリューの磨耗の関係を示すと第 6 図お よび第7図となる。

本穖の使用上最も重視すべきことは内胴スクリュー先 端部の磨耗であつて，これによつて内外胴のバランスも 崩れ易く，その程度如何により直接修繥費に影響し，そ の耐用程度が本機の死命党制するとも考えられる。崎戸 に抢ける第一次試験ではスクリューに軟鋼を便用し，ま た回転差が $4.5 \mathrm{rpm}$ で多過ざたため磨耗が著しかつた。 第二次試験では神戸製鋼 HF\#12 そ用い，スクリュー回 転差を $20 \mathrm{rpm}$ としたので $2,500 \mathrm{~h}$ 連続運転が可能であ つた。2号機にはステライト究用いているが，1,400h 連続運転に対して HF\#12 の約1/2程度の磨耗である。

スクリュー磨耗により間隍が大となると,

(1)振動の発生。処理量の低下。脱水性能の低下。等 の原因となるので，使用材質の吟味は特に重要である。 間㗂は最大 $6 \mathrm{~mm}$ 位まで運転可能と思われる。

スクリンーの磨耗は主に給液フィード口附近及び搔上 げのビーチの部分に起り，プールの部分はは余り磨耗しな い。また磨耗および運転上最も閒題になつているのは,
ケーキ吐出口に附着する微粉で, この掻落しのためにケ 一キ出口の外胴に搔羽根（ステライト盛り）をつけて見 たが，損耗が甚しく，かつ附着がひどくなると排出口に ケーキが停滞し，摩擦抵抗がひとくなることがある。こ の点吐出口で全量が直ちに落下する様改善を図らなけれ ばならない。

\section{4 脫 水 成 績}

崎戸，美唄両砿業所の代表的成績ならびに粒度分析結 果は第 4,5,6 表の通りである。

給液中に含まれる微粉量 (-200 mesh) は美唄が崎戸に 比して約 $30 \%$ 程度少ないにもかかわららず，ケー半湿分 が26\%もあるのは遠心力の不足のためであると思われる。

第4表 脱 水成 績 (陭戶)

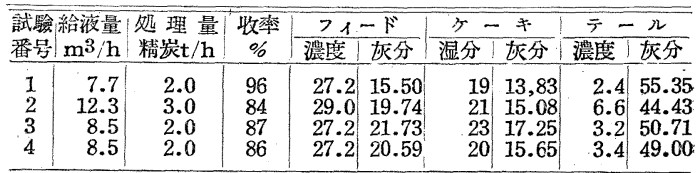

第 5 表 粒度分析成績 (崎戶)

\begin{tabular}{|c|c|c|c|c|c|c|c|c|}
\hline \multicolumn{2}{|c|}{$\begin{array}{l}\text { 試驗 } \\
\text { 番号 }\end{array}$} & \multicolumn{2}{|c|}{$\begin{array}{l}+30 \\
\text { mesh }\end{array} \mid 30 \sim 60$} & \multicolumn{2}{|c|}{$1^{60 \sim} 100^{100 \sim}$} & $\begin{array}{r}200 \sim \\
300\end{array}$ & \multicolumn{2}{|c|}{-300 計 } \\
\hline 1 & 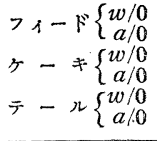 & $\begin{array}{r}11.0 \\
4.02 \\
11.5 \\
4.00 \\
- \\
-\end{array}$ & $\begin{array}{c}15.4 \\
4.09 \\
16.0 \\
4.00 \\
-\end{array}$ & $\begin{array}{c}17.9 \\
4.43 \\
18.6 \\
4.39 \\
-\end{array}$ & $\begin{array}{c}20.2 \\
6.71 \\
21.0 \\
6.63 \\
- \\
-\end{array}$ & $\begin{array}{l}11.9 \\
15.69 \\
12.4 \\
15.65 \\
\end{array}$ & $\begin{array}{c}23.6 \\
44.12 \\
20.5 \\
41.86 \\
100.0 \\
55.35\end{array}$ & $\begin{array}{c}100.0 \\
15.50 \\
100.0 \\
13.83 \\
100.0 \\
55.35\end{array}$ \\
\hline 2 & 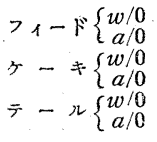 & $\begin{array}{c}8.9 \\
4.19 \\
10.5 \\
4.24 \\
-\end{array}$ & $\begin{array}{c}9.7 \\
4.31 \\
11.5 \\
4.21 \\
-\end{array}$ & $\begin{array}{c}13.9 \\
3.99 \\
16.5 \\
3.93 \\
- \\
-\end{array}$ & $\begin{array}{c}20.5 \\
5.71 \\
24.4 \\
5.64 \\
-\end{array}$ & $\begin{array}{l}12.7 \\
13.73 \\
15.1 \\
13.69 \\
-\end{array}$ & $\begin{array}{c}34.3 \\
45.13 \\
22.0 \\
45.74 \\
100.0 \\
44.43\end{array}$ & $\begin{array}{l}100.0 \\
19.74 \\
100.0 \\
15.08 \\
100.0 \\
44.43\end{array}$ \\
\hline 3 & 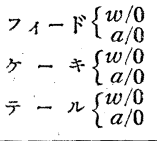 & $\begin{array}{l}1.6 \\
4.20 \\
1.8 \\
4.18 \\
-\end{array}$ & $\begin{array}{l}4.2 \\
4.37 \\
4.6 \\
4.34 \\
- \\
\end{array}$ & $\begin{array}{c}12.3 \\
4.52 \\
13.5 \\
4.53 \\
- \\
-\end{array}$ & $\begin{array}{c}21.4 \\
5.69 \\
23.5 \\
5.64 \\
-\end{array}$ & $\begin{array}{l}15.8 \\
11.72 \\
17.4 \\
11.47 \\
-\end{array}$ & $\begin{array}{c}44.7 \\
39.95 \\
39.2 \\
33.28 \\
100.0 \\
50.71\end{array}$ & $\begin{array}{c}100.0 \\
21.73 \\
100.0 \\
17.25 \\
100.0 \\
50.71\end{array}$ \\
\hline 4 & 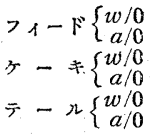 & $\begin{array}{l}2.1 \\
3.42 \\
2.4 \\
3.34\end{array}$ & $\begin{array}{c}13.1 \\
3.91 \\
15.2 \\
3.87 \\
-\end{array}$ & $\begin{array}{c}15.7 \\
4.81 \\
18.3 \\
4.79 \\
-\end{array}$ & $\begin{array}{c}20.0 \\
6.53 \\
23.2 \\
6.44 \\
-\end{array}$ & $\begin{array}{l}14.0 \\
14.17 \\
16.3 \\
14.22 \\
\end{array}$ & $\begin{array}{c}35.1 \\
45.49 \\
24.6 \\
41.86 \\
100.0 \\
49.00\end{array}$ & $\begin{array}{c}100.0 \\
20.59 \\
100.0 \\
15.65 \\
100.0 \\
49.00\end{array}$ \\
\hline
\end{tabular}

第 6 表 粒度分析成績（美唄）

\begin{tabular}{|c|c|c|c|c|c|c|c|c|}
\hline & 跋度\% & & $\begin{array}{l}+28 \\
\text { mesh }\end{array}$ & $28 \sim 60$ & 60 & $\begin{array}{c}100 \sim \\
200\end{array}$ & $|-200|$ & 計 \\
\hline フィード & 38.0 & $\begin{array}{l}w / 0 \\
a / 0\end{array}$ & $\begin{array}{l}3.1 \\
5.21\end{array}$ & $\begin{array}{c}32.0 \\
7.90\end{array}$ & \begin{tabular}{|c|}
10.3 \\
8.33
\end{tabular} & $\begin{array}{l}30.6 \\
10.24\end{array}$ & $\begin{array}{l}24.0 \\
16.23\end{array}$ & $\begin{array}{c}100.0 \\
10.58\end{array}$ \\
\hline$r-\neq$ & $\begin{array}{c}\text { (湿分) } \\
26.0\end{array}$ & $\begin{array}{l}w / 0 \\
a / 0\end{array}$ & $\begin{array}{l}2.8 \\
5.80\end{array}$ & $\begin{array}{c}27.7 \\
7.75\end{array}$ & $\begin{array}{c}11.7 \\
8.25\end{array}$ & $\begin{array}{c}39.0 \\
9.34\end{array}$ & \begin{tabular}{|l|}
18.8 \\
14.94
\end{tabular} & $\begin{array}{r}100.0 \\
9.73\end{array}$ \\
\hline$\tau-$ & 0.37 & $\begin{array}{l}w / 0 \\
a / 0\end{array}$ & = & E & $=$ & $=$ & $\left|\begin{array}{c}100.0 \\
27.24\end{array}\right|$ & $\begin{array}{c}100.0 \\
27.24\end{array}$ \\
\hline
\end{tabular}

\section{6. 脫水成績に対する考察}

\section{1 脫 水 効 果}

今汽の試験結果と操業中における成績を総括して考え ると，脱水成績に影響するファクタとしては，機械的條 件を一定とした場合，フィードの粒度，量，濃度が主であ ると云うことが出来る。その中フィードの粒度による影 
響が一番大きく，脱水炭湿分との関係をプロットすると 第 8 図の如くなる。この場合, 普通の操業状態で崎戸は >ィード量 2 2.5 t/h (固形物), 濃度 $25 \sim 30 \%$, 美唄 は>ィード量 3.5 4.0 t/h (固形物), 濃度 35 40\%の 範囲のものをとつた。美唄の場合脱水湿分が高いのは， 前述したごとく回転数をおとしているので，遠心效果が

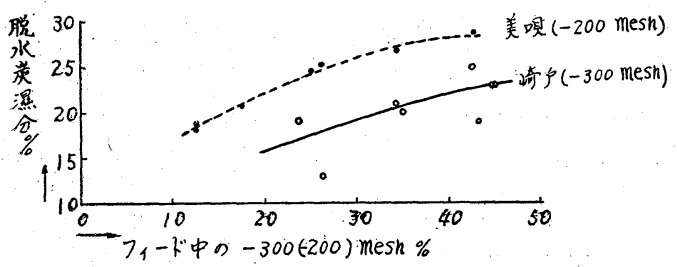

第 8 図 フィード粒度 $(-300$ mesh $)$ 々脫水湿分

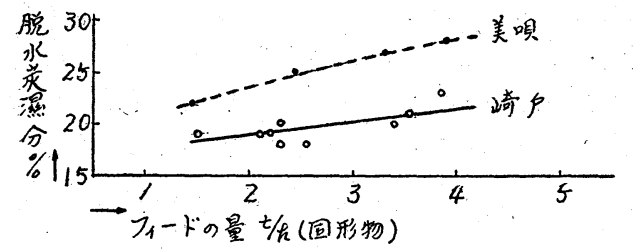

第 9 図 フィードの量 (固形物) 上脫水炭湿分

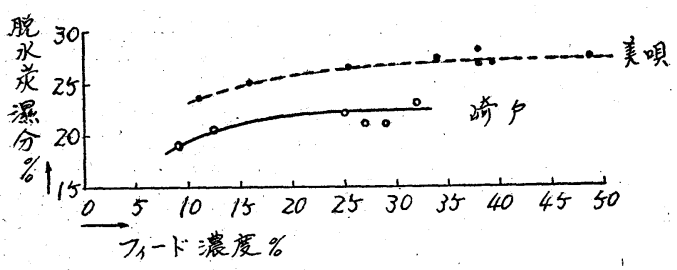

第10図 フィード濃度と脫水炭湿分

少ないためと思われる。

またフ 図の如くなる。この場合崎户では〉 ィード濃度25〜30\%， 粒度 - 300mesh 30 40\%，美唄ではつィード濃度 35 40\%，粒度-200mesh 25〜30\%の範囲のものをとつた。 濃度がほほ一定ならば,フィード量はその機械の処理能 力の範囲内ではあまり脱水宸湿分に影響を与えないよう である。

フィードの濃度と脱水㟶湿分の関係は第10図に示す。 この場合崎戸は> ィード量 $2.0 \sim 2.5 \mathrm{t} / \mathrm{h}$ (固形物), 粒度 -300 mesh 30 40\%，美唄は> ィー ド量 3〜4 t/h (固 形物), 粒度 -200 mesh 25 30\% の範囲のものをとつ た。フィード濃度の脱水炭湿分に区更漂导影響は，濃度が 約25\%以上ではほとんぞないが，25\%以下になると濃度 が薄くなる程脱水炭湿分は低下して来る。

\section{2 脫水炭の回收率}

崎戸におおるつ みると，第11図に示す如く，フィード中の -300 mesh の割合に大きく影響される。普通操業 ( -300 mesh 30 〜 40\%程度)では回収率は85〜90\%位は期待出来る。な

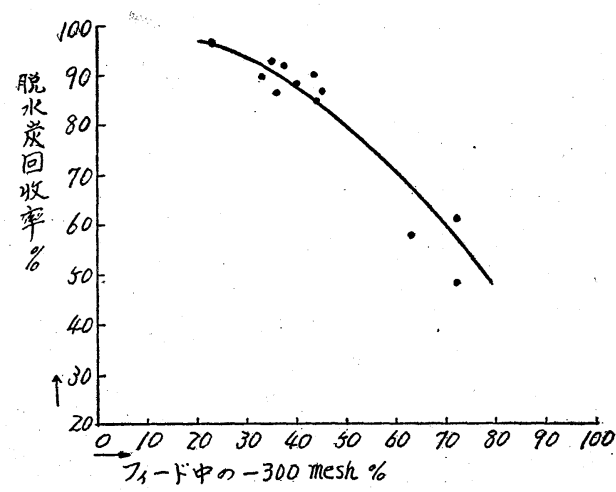

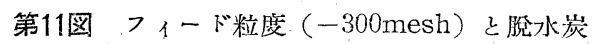
回收率

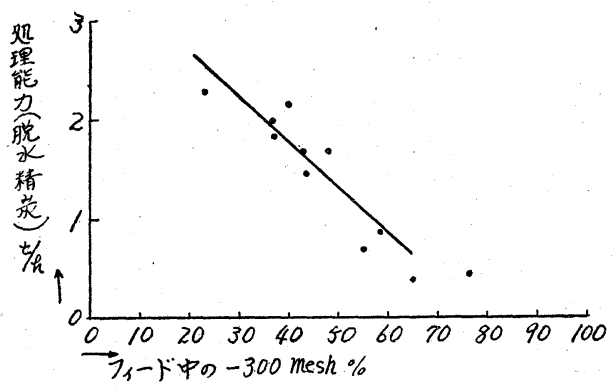

第12図 フィード粒度 (-300mesh) と処理能 力 (脫水精炭)

おこれに対しては，脱水機廃水をさらに浮選機に繰返し 処理すれば，全体としての回収率はもつと向上出来る見 込みである。

\section{3 処 理 能 力}

崎戸における>

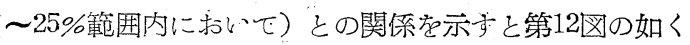
なる。フィード中のー300 mesh の割合が増すにしたが い，著しく処理能力が減ずる。

\section{4 脫水炭の品位向上}

脱水炭の灰分は> 1ーF灭分より 3 5\%低くなる。文 排水中の固形物は灰分の多い -300 mesh から成り，廃 石として除去されている。フィード中の -300 meshは

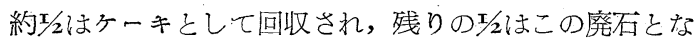
る様である。

\section{5 処理量と電力消費量の関係}

崎戸に抢ける脱水機のプールの長さの変化による処理 量 (脱水精炭) と電力消費量との関係は第13図の如くで ある。この眖水機は無負荷運転では $6 \sim 7 \mathrm{~kW}$ の消費で あるが, 当初の液面半径 $270 \mathrm{~mm}$, プールの長さ $170 \mathrm{~mm}$ では極めて多くの電力を消費した。そこでプールの長さ を $395 \mathrm{~mm}$ にした場合には電力消費量はかなり減少し た。すなわち電力消費量はビーチの長さと处理固形物量 に比例して堌加守るようである。結局据付馬力 $35 \mathrm{~kW}$ 


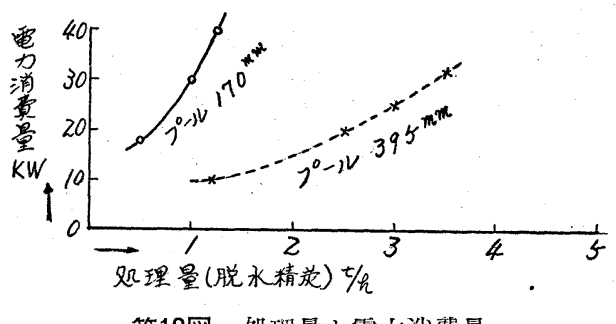

第13図 処理量之麗力消費量

(50 P) で処理量は精炭で。2 2.5 た/h の操業が適当であ るので，電力は 15〜18 kW の消費で足り，据付馬力の $50 \%$ 前後である。操業実績は脱水宸量 $1 t$ 当り $10 \mathrm{kWh}$ 程度の消費であるが, 近時運転も順調となり，処理量も 増加しつつあるので，7〜 $8 \mathrm{kWh} / t$ 程度になる見込であ bo

\section{6 脫 水 経 費}

6.6 .1 寒 績

第7表 脫 水 経 費 (月本均实績)

\begin{tabular}{|c|c|c|c|c|}
\hline 費 目 & 崎 & F & 美 & 唄 \\
\hline 動 力 費 & 5 円 $\times 10 \mathrm{kWh} / \mathrm{t} \times 680 \mathrm{t} / \mathrm{J}$ & $=34,000$ 円 & 5 円 $\times 10.5 \mathrm{kWh} / \mathrm{t} \times 840 \mathrm{t} /$ & 月 $=44,100$ 円 \\
\hline 人 件 費 & 450 円 $\times 1$ 人 $\times 2$ 方 $\times 25$ 日 & $=22,500$ 円 & $\begin{array}{l}350 \text { 円 } \times 0.5 \text { 人 } \times 2 \text { 方 } \times 25 \text { 日 } \\
\text { (請顀) }\end{array}$ & \\
\hline $\begin{array}{l}\text { 修理 費 } \\
\text { (含物品賁) }\end{array}$ & & 11,500 円 & & 21,000 円 \\
\hline 減価償却費 & 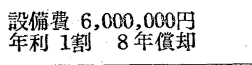 & 87,500 円 & 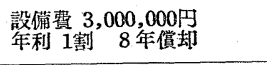 & 43,750 円 \\
\hline 計 & & 155,500 円 & & 117,600 円 \\
\hline 精炭 $\mathrm{t}$ 当り & 155,500 円 $\div 680 t \fallingdotseq 228$ P & & 117,600 円 $\div 840 \mathrm{t} \fallingdotseq 140$ 円 & \\
\hline
\end{tabular}
い。 扱心易い。

める割合に最も影響される。ー-300 mesh 30〜40\%迄は 湿分 $20 \%$ 程度に迄脱水可能である。余り微粒子の多いも のに対しては，粗粒分を或る程度混大してやることが， 脱水効果と姏理能力の点からみて必要である。

(3) 㚮理能力もフィード中の微粒子の割合に大きく 影響される。微粒子が多くなると或る程度の脱水宸湿分 を期待するためには著しく処理量を減じなければならな

（4）脱水炭は本機によりデスライミングされるため， 原炭に比して灰分が約 4\%低下し，※たさらさらして取

（5）故障個所は初期には，差動装置の心゙ャッングお よび萊車の損傷，スクリューの磨耗が主なものであつ た。差動装置はその後材質と穖構の点が改善され，今の 所問題はないと思われる。スクシューの磨耗に対しては ステラィトの場合 $2,500 〜 3,500 \mathrm{~h}$ の実績を示しているの で，予供品总持つか又は硬化材の 肉盛をなすかの方法で解決出来る 見通しである。

(6) 耐用命数の点を考慮して 脱水可能な限り回転数及び回転差 はなる心くく少なくすることが望ま しい。フィード中のー300 mesh, 30〜40\%以下では脱水崖湿分な20 \%前後にすると，液面における遠 心効果は600位で充分と思われる。

脱水経費は 1 力月平均の塞績を第 7 表に示す。崎戸の 経費は今後電力消費量の減少々処理量 (精㞸量) の増加 により精炭 $1 \mathrm{t}$ 当り 170〜200円になる見込みである。

\section{6 .2 遠心脱水機とフィルタの比較}

フィルダの脱水に抢いてはシックナ， ポンプ等の附雁 設備を要し，かつ建家面積が広くなるので設備費が高く なる。例えば今 $6 \mathrm{t} / \mathrm{h}$ の脱水被備費はフィルタの場合， 約 1,500 万円，遠心脱水機の場合は約 1,000 万円位之考 えられる。な打脱水経費は今迄の実績より推定すれば, フィルヌの場合は約 200〜250 円/t (含償却)，遠心脱水 機の場合は前記の如く 170～200 円/ $\mathrm{t}$ 位となるので，本 機による微粉脱水は有利と思われる。

\section{7. 結}

\section{言}

連続遠心脱水機を微粉炭の脱水に利用したが，その現 場操業成績を総括的に検钨すれば,

（1）本穖は㵟粉炭の脱水に効果的に使用可能であ 当。

（2）脱水効果については，フィード中の微粒子の占
（7）ビーチの長さは脱水炭湿分の許寸範囲内で短い 方が運転が容易で，動力も少なくてすむ。

（8）脱水経費は約 170 200円/t の見込で，フィルタ に比し遜色なく，かつシックナを要せず建家面積が少な くてすむ。設備費はフィルターに比し約 $70 \%$ 程度であ る。

（9）今後において改良検討を要する点は,

(1) 処理量の增大る計ること。

(口) 精炭吐出口における附着微粉を円滑に搔落すよ うな機構に改造すること。

() スクリュー先端の硬化材肉盛りを炭砇現場で実 施し得るようにし，から容易にバランスのとれる 様に㖬熟すること等である。

\section{附 記}

本稿は当社崎戸砥業所及び美唄砝業所より提出願つた 操業成績資料に基き取緾めたものである。両吰業所関係 各位の御尽力に対し，また資料の整理に当られた当社生 産部營本技師に対し感謝の意を表する。 